\title{
Funkcja kierownika projektu
}

https://doi.org/10.33141/po.2005.02.05

Marek Pawlak

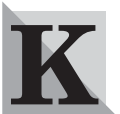

ierownik projektu (KP) według Eisnera [2, s. 96] wykonuje cztery podstawowe funkcje: - planowanie, • organizowanie, - kierowanie, $\bullet$ monitorowanie (nadzorowanie).

Planowanie i organizowanie są istotnymi grupami zadań i zazwyczaj są dobrze wykonywane przez osobę, która lubi postępować metodycznie. Są to działania sztabowe, które mogą być realizowane w ciszy gabinetu, nawet bez współpracy z innymi ludźmi. Można je także określić funkcjami projektowymi. Osoba lubiąca wykonywać tego typu prace będzie miała tendencję do zachowań introwertycznych i będzie wymagała znacznego porządku i dyscypliny, od siebie i od innych [2, s. 96]. Kiedy jednak przejdziemy do funkcji kierowania i nadzorowania, od razu możemy dostrzec, że stawiają one zupełnie inne wymagania. Realizacja tych prac wymaga interakcji z innymi ludźmi. Kierowanie wymaga przypisania ludziom zadań i doradzania im w wykonywaniu tych zadań, włączając $\mathrm{w}$ to monitorowanie i reagowanie w przypadku, gdy stan rzeczywisty odbiega od pożądanego. Takie funkcje zawierające interakcje z innymi ludźmi są zazwyczaj dobrze wykonywane przez ludzi o usposobieniu ekstrawertycznym, którzy chętnie dyskutują z innymi i nie lubią wykonywać „papierkowej pracy” związanej z przygotowywaniem planów. Już na podstawie tych rozważań można stwierdzić, że kierownik projektu musi wykonywać bardzo różne obowiązki, które wymagają zrównoważonej osobowości. KP powinien być osobą dobrze zintegrowaną, która jest w stanie zmieniać sposób swojego działania i utrzymać równowagę między wieloma kwestiami, które nieuchronnie pojawią się w jego pracy [2, s. 96].

\section{Zadania kierownika projektu}

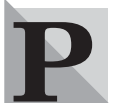

unktem wyjścia do rozpatrywania funkcji określonej osoby w organizacji są zwykle realizowane przez nią zadania. W odniesieniu do funkcji KP zadania te są dość liczne, zróżnicowane i podawane w różnym układzie w literaturze z zakresu zarządzania projektami. Są one z zasady rozwinięciem czterech wymienionych wcześniej podstawowych grup. Przykładowo [9, s. 11.4] wymienia się następujące ważniejsze zadania:

- określenie struktury organizacyjnej projektu,

- sformułowanie celów projektu i przedłożenie ich zleceniodawcy do zatwierdzenia,

- strukturalizacja projektu i ustalenie grupy projektowej,
Przegląd Organizacji, Nr 2 (781), 2005, ss. 22-25 www.przegladorganizacji.pl Towarzystwo Naukowe Organizacji i Kierownictwa (TNOiK)
- planowanie i nadzorowanie terminów i kosztów, - nadzorowanie realizacji projektu z punktu widzenia osiągnięcia celów,

- zapewnienie wymiany informacji (posiedzenia, sprawozdania itd.) i systemu dokumentowania,

- przygotowanie ważnych decyzji i wprowadzanie ich w życie,

- kierowanie grupa projektową.

Określenie struktury organizacyjnej to zadanie wybitnie sztabowo-planistyczne. Na podstawie cech projektu trzeba tu dokonać wyboru typu struktury, np. macierzowa lub „czysta” i opracować szczegóły dotyczące zakresu odpowiedzialności i kompetencji KP. Istotną kwestią jest też rozgraniczenie kompetencji kierowników liniowych i KP w przypadku struktury macierzowej bądź organizacyjne „zakotwiczenie” grupy projektowej w przypadku struktury „czystej”.

Cele projektu określa z reguły zleceniodawca, ale ich sformułowanie to zadanie przede wszystkim kierownika projektu. Wyróżnia się tu cele systemu (określające funkcje systemu, który ma być stworzony) i cele projektu formułowane w kategoriach terminów, kosztów, jakości. Cele obu grup są wzajemnie powiązane i tworzą z reguły skomplikowany system celów.

Strukturalizacja projektu to przede wszystkim zaplanowanie procesu jego realizacji, określenie zadań cząstkowych, zaplanowanie niezbędnych zasobów, w tym szczególnie ustalenie grupy projektowej. KP nie ma jednak z zasady prawa przydzielania konkretnych osób do zespołu projektowego, może jedynie określić kwalifikacje osób, jakie są niezbędne.

Planowanie terminów i kosztów, a także ich nadzorowanie to z jednej strony zadanie sztabowe (planowanie), z drugiej operacyjne (nadzorowanie). Planowanie realizowane jest częściowo przed rozpoczęciem prac (planowanie wstępne), częściowo w trakcie realizacji (planowanie szczegółowe). Nadzorowanie polega na porównywaniu rzeczywistego przebiegu realizacji prac z pożądanym (określonym w planach) i w przypadku istnienia istotnych odchyleń podejmowaniu działań korygujących.

Nadzorowanie realizacji projektu z punktu widzenia osiagnięcia celów to zadanie czysto operacyjne. $\mathrm{O}$ ile cele systemu formułowane są przede wszystkim w kategoriach funkcji, jakie ma spełniać dany obiekt (porównaj [1, s. 68]), to kontrola polega tu na sprawdzeniu przy pomocy jakich rozwiązań strukturalnych, technicznych, materiałowych cele zostały osiągnięte.

Zapewnienie wymiany informacji (posiedzenia, sprawozdania itd.) $i$ systemu dokumentowania to zadanie częściowo sztabowe, ale w znacznie większym zakresie operacyjne. Posiedzenia trzeba planować 
z punktu widzenia celów, przebiegu, zaprosić odpowiednie osoby, ale w trakcie realizacji trzeba sterować (kierować) ich przebiegiem. System dokumentowania obejmuje zebranie i przechowywanie ważnych rezultatów projektu, także tych nie wykorzystanych, do celów kontrolnych, ale także jako źródła wiedzy dla przyszłych projektów.

Kierownik projektu nie ma z zasady prawa podejmować ważnych decyzji dotyczacych np. wyboru wariantów rozwiązań, zatwierdzenia budżetu, przydziału środków do realizacji projektu. Ma jedynie obowiązek przygotować te decyzje (np. przez zbadanie skutków różnych wariantów działań) i następnie wprowadzić je w życie.

Kierowanie grupa projektowa to zadanie typowo operacyjne, ale nie jest to funkcja kierownicza w tradycyjnym taylorowskim znaczeniu. KP ma tu za zadanie stworzyć zespół, rozwiązywać konflikty, motywować, wspierać procesy komunikowania się, reprezentować zespół na zewnatrz.

W podobny sposób określają zadania kierownika projektu Litke [11, s. 174-175], Lentz i Rea [10, s. 98-99], Kezsbom i Edward [8, s. 256-257]. Heeg [5, s. 159-160] dzieli zadania kierownika projektu na następujące grupy: organizacja projektu, planowanie i sterowanie; fachowa odpowiedzialność za realizację zadań; koordynowanie i informowanie; analiza efektywności ekonomicznej; zadania kierownicze.

$\mathrm{Na}$ uwagę zasługuje przede wszystkim duża różnorodność tych zadań. Należą one do różnych grup funkcji, które w przedsiębiorstwie są realizowane zwykle przez wyspecjalizowanie komórki lub całe piony organizacyjne. W związku z tak dużą różnorodnością zadań funkcja kierownika projektu określana jest czasem mianem funkcji prezesa zarządu w miniaturze.

\section{Wiedza i umiejętności}

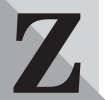

dużej różnorodności zadań wynikają duże wymagania stawiane kierownikowi projektu. Wymagania te są różnie grupowane. Przykładowo Litke [11, s. 173] dzieli je na wymagania dotyczące wiedzy, doświadczenia, umiejętności i osobowości. Podobny podział proponuje Kellner [6, s. 124-125]. Z kolei Hansel i Lomnitz [4, s. 211] w ramach kwalifikacji kierownika projektu wyróżniają wiedzę fachową, wiedze metodyczna i kwalifikacje społeczne. Wiedza fachowa związana jest bezpośrednio $\mathrm{z}$ dziedziną, $\mathrm{w}$ jakiej realizowany jest projekt. Z reguły nie wymaga się od kierownika projektu, aby był on w tej dziedzinie ekspertem. Biorąc pod uwagę interdyscyplinarność projektów, nie jest nawet możliwe, aby KP był ekspertem w każdej z dziedzin cząstkowych. Wystarczy, jeśli będzie miał fachowców w zespole, będzie mógł się z nimi komunikować i będzie mógł organizować komunikację między nimi. Sam powinien posiadać podstawowe kompetencje w dziedzinie, w której projekt jest realizowany.

Zupełnie inaczej przedstawia się sytuacja z punktu widzenia wiedzy metodycznej. Chodzi tu w szczególności o wiedzę na temat metod i technik zarządzania projektem. Można tu w szczególności wymienić znajomość technik planowania procesu projektu, planowania struktur organizacyjnych, oceny efektywności ekonomicznej projektu, planowania ryzyka, aż do technik rozwiązywania problemów, prezentacji danych, organizowania spotkań.

\section{Kwalifikacje społeczne}

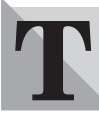
rzecia grupa wymagań to kwalifikacje społeczne. Celowo użyte tu zostało słowo „kwalifikacje”, a nie „umiejętności” czy „wiedza”, ponieważ duże znaczenie odgrywają tu cechy osobowe. Kerzner twierdzi, że to właśnie cechy osobowe decydują o wyborze kierownika projektu, a nie zakres pracy, która ma być wykonana, i podaje następujący pożądany zestaw cech osobowych [7, s. 162]:

- elastyczność i zdolność adaptacji,

- posiadanie inicjatywy i zdolności przywódczych,

- zdolność do agresywnych zachowań, budzenie zaufania, umiejętność przekonywania, płynność werbalna,

- ambicja, aktywność, umiejętność postawienia na swoim,

- efektywność działania w komunikowaniu i integrowaniu,

- szeroki zakres osobistego zaangażowania,

- zrównoważenie, entuzjazm, wyobraźnia, spontaniczność,

- zdolność równoważenia rozwiązań technicznych z ograniczeniami czasu, kosztów i czynnika ludzkiego,

- dobrze zorganizowany i zdyscyplinowany,

- raczej generalista niż specjalista,

- zdolny do poświęcenia większości swojego czasu na planowanie i kontrolowanie,

- zdolny do identyfikowania problemów,

- zdolny do podejmowania decyzji,

- zdolny do utrzymania odpowiedniej równowagi w gospodarowaniu czasem.

Podobną listę pożądanych cech osobowych kierownika projektu przedstawia Kellner [6, s. 125]. Pisze on ponadto, że w przypadku osób dorosłych są one już relatywnie mocno ukształtowane. Cechy osobowe sa częściowo wrodzone, częściowo ukształtowane przez wychowanie, wzorce zachowań, warunki życia itp. Każdy człowiek ma szczególnie w tej dziedzinie słabości, których mimo dużych wysiłków nie jest w stanie zniwelować. Ważne jest, aby znał własne słabości i aby miał zasadniczo pozytywne nastawienie do innych ludzi. Wtedy będa oni także gotowi do akceptowania „niedoskonałości” KP. Należy tu także uwzględnić, aby KP „niedoskonałości” współpracowników traktował również z wyrozumiałością [6, s. 126].

Niekiedy pożądane cechy osobowe i zdolności kierownika projektu są dzielone na dwie grupy - oczekiwań ze strony gremium wybierającego i wtedy kierownik projektu jest traktowany jako podwładny oraz oczekiwań jako przełożonego zespołu projektowego. Przykładowo Haberfellner proponuje tu następująca listę [3, s. 2101].

- Jakie cechy i zdolności powodują, że konkretna osoba wydaje się interesująca z punktu widzenia gremium wybierającego kierownika projektu: 
- zaangażowany, zainteresowany, umotywowany;

- nieskomplikowany, systematyczny, który podąża prostą linią i któremu można powierzyć projekt w sensie fachowym i organizacyjnym względnie administracyjnym;

- jest w stanie dać sobie radę także ze skomplikowanymi ludźmi: rzeczowy, wspaniałomyślny, gotowy do rozmów, przyjaźnie nastawiony, zrównoważony;

- zdolny do znoszenia obciążeń, nie nadwrażliwy (jak mimoza);

- zdolny do postawienia na swoim, także bez posiadania (odpowiednich) formalnych kompetencji;

- posiadajacy wiedzę fachową, zdolny i gotowy do uczenia się;

- zdolny poświęcić dla projektu wystarczającą ilość czasu;

- dobry, uczciwy i przekonywujący negocjator;

- zdolny porozumieć się z przyszłym użytkownikiem (systemu).

- Jakie cechy i zdolności powoduja, że osoba jest odpowiednia jako członek (kierownik) zespołu:

- kompetentny w sensie fachowym (nie musi jednak i nie powinien chcieć być najlepszym fachowcem we wszystkich sprawach);

- powinien mieć zdolności prawidłowej oceny;

- powinien mieć jasną linię postępowania;

- powinien wierzyć w celowość i sukces projektu;

- duże osobiste zaangażowanie i dawanie wzoru (przykładu) swoim postępowaniem innym;

- dobry moderator: pozwala, aby inni byli dobrzy i stawali się jeszcze lepsi, prowadzi, motywuje; powoduje, że mniej wydajni pracownicy stają się wydajniejsi, przydziela im możliwe do pokonania zadania;

- daje coś więcej, pozwala uznać postęp i wyniki, stwarza dobry nastrój i poczucie wspólnoty (ale nie kosztem innych);

- jest w stanie „sprzedać” projekt na zewnątrz;

- postępuje uczciwie i uznaje sukcesy innych.

\section{Charakterystyka kierownika projektu wedtug Eisnera}

Eisner [2, s. 97-102] podaje i opisuje dwadzieścia pożądanych cech KP, określając je także jako „charakterystykę dobrego przełożonego”. Cechy te można przypisać do trzech grup i sformułować następująca ustrukturalizowaną charakterystykę:

- Cechy własne: - odpowiednio deleguje władzę; - jest zdyscyplinowany; • jest w stanie się poświęcić, aby osiągnąć cele; $\bullet$ jest zrównoważony; $\bullet$ podejmuje inicjatywy; $\bullet$ jest kreatywny;

- Interakcje z innymi ludźmi: @ dobrze komunikuje się z innymi ludźmi i dzieli się informacjami; - wspiera i motywuje ludzi; • jest dobrym słuchaczem; • jest otwarty na opinie innych ludzi i elastyczny; • udziela konstruktywnej krytyki; • ma pozytywne nastawienie; • jest dobrym budowniczym zespołu (projektowego) i członkiem zespołu (przedsiębiorstwa); • jest w stanie dobierać i oceniać ludzi; • ma odwagę i umiejętność rozwiązywania konfliktów;

- Umiejętności: - odpowiednio deleguje władzę; - jest kompetentny w dziedzinie, w której realizowa- ny jest projekt; • umie rozwiązywać problemy; $\bullet$ jest dobrym integratorem; $\bullet$ umie podejmować decyzje.

Można zwrócić uwagę, że najwięcej wymagań znalazło się w grupie dotyczącej interakcji z innymi ludźmi, co świadczy o dużym znaczeniu tej grupy cech.

\section{Idealny kierownik projektu}

Lista wymagań stawianych kierownikowi projektu jest obszerna i niezwykle różnorodna. Kerzner nawiązując do tego twierdzi żartobliwie: ,idealny menedżer projektu musiałby mieć prawdopodobnie doktorat $\mathrm{z}$ nauk technicznych, ekonomii i psychologii, doświadczenie z pracy w różnych przedsiębiorstwach, na różnych stanowiskach, w różnych projektach i powinien mieć około 25 lat. Dobrzy menedżerowie projektów pracujący obecnie w przemyśle byliby szczęśliwi mając około 70 do $80 \%$ tych cech" [7, s. 162].

Z kolei Haberfellner uważa, że tak sformułowane profile wymagań tworzą jedynie wyimaginowany obraz „herosa projektu”, który normalnych ludzi może jedynie wprawić $\mathrm{w}$ zakłopotanie i który z reguły nie zostanie zaakceptowany. W związku z tym wydaje się rzeczą bardziej realistyczną wyjść z założenia, że nie ma idealnego kierownika projektu i taki w ogóle nie jest potrzebny [3, s. 2099].

Podobnego zdania jest Litke, który twierdzi, że realistycznie patrząc, nigdy nie znajdzie się KP, który spełniałby te wszystkie wymagania. Istotną dla kierownika projektu rzeczą jest przede wszystkim zdolność działania generalnego i nieangażowania się zbyt głęboko w rzeczowe szczegóły projektu [11, s. 172].

\section{Od czego zalè̇a wymagania}

Wymagania stawiane kierownikowi projektu zależą od rodzaju projektu i cech członków zespołu. Są projekty, które w ogóle nie wymagają kierowania - mimo że z punktu widzenia sformułowanych celów mogą być bardzo wymagające. Są to przykładowo sytuacje, w których wszystkie warunki są zgodne z oczekiwaniami, projekt szybko okazuje się bardzo atrakcyjny i zyskuje zwolenników; ludzie uczestniczą w nim z zainteresowaniem i przyjemnością, przełożeni traktuja go z życzliwością i zainteresowaniem itd. Tego rodzaju projekty potrzebują wprawdzie trochę administracji, ale nie wymagają intensywnego kierowania. Pojawiające się problemy rozwiązywane są z reguły szybko, bez biurokracji i bez napięć [3, s. 2100].

Z drugiej strony zdarzają się oczywiście także projekty, które z punktu widzenia postawionych celów wydają się mało kłopotliwe, ale mimo to trudne do realizacji. Przyczyną tego może być fakt, że nie wydają się one atrakcyjne; nie ma osób naprawdę zainteresowanych projektem, warunki i środowisko są niesprzyjające. Tego rodzaju projekty muszą być najpierw „sprzedane" na zewnątrz i do wewnątrz (organizacji), aby stały się atrakcyjne. Jeżeli nie ma osoby odpowiedniej lub nie znajdzie się nikt, komu by się to udało, lub kto byłby przekonany o sensowności projektu i jego szansach na sukces, byłoby lepiej zrezygnować z realizacji. W uzupełnieniu można dodać, że wciąż 
spotyka się osoby, dla których takie trudności stanowią jedynie wyzwanie [3, s. 2100].

\section{Konieczność wsparcia z góry}

Zarządzanie projektem nie może się zakończyć sukcesem, jeśli nie znajdziemy dobrego menedżera projektu. Za proces selekcji ponosi odpowiedzialność kierownictwo wyższego szczebla, ponieważ później dla menedżera projektu delegowana jest władza zarząu przecinająca różne organizacyjne piony. Jest o wiele bardziej prawdopodobne, że menedżer projektu osiągnie sukces, jeśli wszyscy członkowie organizacji będą wiedzieli, że został przez zarząd powołany. Zwykle wystarczy tu krótkie pismo do kierowników pionów funkcjonalnych [7, s. 160].

Litke uważa, że sukces projektu zależy od tego, w jakim stopniu zarząd „stoi” za decyzjami KP. Dla skutecznej pracy KP jest rzeczą konieczną, aby otrzymywał on pełne poparcie od kierownictwa przedsiębiorstwa i aby to poparcie było potwierdzone i znane wszystkim osobom zaangażowanym w projekt [11, s. 170]. Zarząd występuje tu w stosunku do menedżera projektu jako tzw. promotor władzy [11, s. 175].

\section{Osoba z wnętrza i spoza przedsiębiorstwa}

Kierownik projektu może być zaangażowany $\mathrm{z}$ wnętrza przedsiębiorstwa lub z jego otoczenia. Oba te rozwiązania maja swoje zalety. Przykładowo Kerzner wymienia następujące korzyści zatrudnienia osób z wnętrza przedsiębiorstwa [7, s. 166]:

- znaja oni organizację, polityki, procedury i kluczowych ludzi; umożliwia im to szybsze osiagnnięcie wysokiej jakości działania;

- poziom ich działania jest znany i sprawdzony, co umożliwia przełożonym umieszczenie ich na maksymalnym poziomie odpowiedzialności i władzy;

- klienci preferuja sprawdzony poziom współpracy z organizacją, która aktualnie zatrudnia menedżera projektu.

Można także wskazać zalety angażowania KP spoza przedsiębiorstwa. Nowy menedżer projektu zaangażowany $\mathrm{z}$ zewnątrz będzie miał prawdopodobnie mniej nieformalnych powiązań z komórkami liniowymi i dzięki temu projekt będzie realizowany bezstronnie. Niektóre przedsiębiorstwa wymagają w związku z tym, aby dana osoba odbyła najpierw praktyke w przedsiębiorstwie w czasie od dwunastu do osiemnastu miesięcy w komórce liniowej, aby poznać, jak organizacja funkcjonuje, aby zapoznać się z niektórymi ludźmi i aby zrozumieć obowiązujące polityki i procedury [7, s. 166].

\section{Dlaczego kwalifikacje spoteczne sa takie ważne?}

Chociaż w nowoczesnej gospodarce przy dokładniejszych badaniach można znaleźć jeszcze wszystkie możliwe style kierowania, to w minionych latach dał się zaobserwować trend, który polega głównie na odejściu od autokratycznego w kierunku partycypacyjne- go stylu kierowania i na tym, że to człowiek coraz częściej stawiany jest jako główny punkt zainteresowań [11, s. 175]. Pracownik nie jest traktowany tylko jako wykonawca poleceń. Wyrazem tego jest z pewnością zaangażowana wymiana informacji pomiędzy kierownikiem i jego podwładnym [11, s. 178]. Działania mechaniczne i powtarzalne występują w coraz mniejszym zakresie, natomiast na znaczeniu zyskują działania, w przypadku których określany jest jedynie cel, ale nie jest podawana przez przełożonego prowadząca do niego droga [11, s. 180].

W stosunku do współpracowników w projekcie o wysokich kwalifikacjach i wysokiej odpowiedzialności przełożony musi stosować kooperacyjny styl kierowania, który umożliwi stworzenie dla członków zespołu dużej swobody decydowania i działania [11, s. 180].

Kierownik zespołu projektowego nie występuje w roli tradycyjnego przełożonego. Rosnące kwalifikacje członków zespołu prowadzą do tego, że stają się oni coraz bardziej samodzielni i pewni siebie. W związku z tym nie powinni oni otrzymywać pojedynczych poleceń, ale całe „pakiety zadań”. Takie pakiety zadań powinny zawierać cele działań, na podstawie których będą mogli oni samodzielnie pracować. Właśnie w takim środowisku pracy, jak realizacja projektu, przełożony jest w coraz większym zakresie uzależniony od „samodzielnego funkcjonowania” swoich wspó1pracowników, w tym nie tylko od ich kwalifikacji zawodowych, ale także od ich zachowań, lojalności i solidarności [11, s. 180].

dr hab. prof. KUL Marek Pawlak kierownik Katedry Zarządzania Przedsiębiorstwem Instytut Zarzadzania i Marketingu Katolicki Uniwersytet Lubelski

\section{BIBLIOGRAFIA}

[1] DAENZER W.F., Systems Engineering. Leitfaden zur methodischen Durchführung umfangreicher Planungsvorhaben, Industrielle Organisation, Zürich 1988.

[2] EISNER H., Essentials of Project and Systems Engineering Management, John Wiley \& Sons, New York 1997.

[3] HABERFELLNER R., Projektmanagement, w: Handwörterbuch der Organisation, Verlag C.E. Poeschel 1992.

[4] HANSEL J., LOMNITZ G., Projektleiter-Praxis, Springer, Berlin 1987.

[5] HEEG F.J., Projektmanagement, Carl Hanser, München 1993.

[6] KELLNER H., Projekte konfliktfrei führen, Carl Hanser, München 2000.

[7] KERZNER H., Project Management, Van Nostrand Reinhold Company, New York 1984.

[8] KEZSBOM D., EDWARD K., The New Dynamic Project Management, John Wiley \& Sons, New York 2001.

[9] KUMMER W., SPÜHLER R., WYSSEN R., Projekt Management, Industrielle Organisation, Zürich 1988.

[10] LIENTZ B., REA K., Project Management for the 21st Century, Academic Press, San Diego 1995.

[11] LITKE H., Projektmanagement, Carl Hanser, München-Wien 1995.

[12] PAWLAK M., Struktury organizacyjne zarzadzania projektami, „Przegląd Organizacji” 1/2004, s. 15-18. 